\title{
AL-IQTISHADIYAH
}

Jurnal Ekonomi Syariah dan Hukum Ekonomi Syariah

E-ISSN: 2621-0274; P-ISSN: 2442-2282

Volume 6, Nomor 1, Juni 2020

\section{PENERAPAN PRINSIP SYARIAH DI PASAR MODAL MELALUI SOTS (SHARIA ONLINE TRADING SYSTEM)}

\section{Khabib Musthofa}

Institut Agama Islam Negeri Palangka Raya, Indonesia. Email: khabibmusthofa1996@gmail.com

\begin{tabular}{|c|c|}
\hline ARTICLE INFO & ABSTRACT \\
\hline $\begin{array}{l}\text { Kata Kunci: } \\
\text { Pasar modal; Saham; } \\
\text { SOTS } \\
\text { Cara Sitasi: } \\
\text { Musthofa, Khabib. } \\
\text { "Penerapan Prinsip } \\
\text { Syariah di Pasar Modal } \\
\text { Melalui SOTS (Sharia } \\
\text { Online Trading } \\
\text { System)." Al- } \\
\text { lqtishadiyah: Jurnal } \\
\text { Ekonomi Syariah dan } \\
\text { Hukum Ekonomi } \\
\text { Syariah VI, no. } 1 \text { (2020): } \\
\text { 29-43. }\end{array}$ & $\begin{array}{l}\text { Pasar modal syariah di Indonesia sampai saat ini telah } \\
\text { menunjukkan beberapa perkembangan dan kemajuan. } \\
\text { Perkembangan ini terlihat dengan meningkatnya produk pasar } \\
\text { modal. Salah satunya adalah peningkatan perdagangan online } \\
\text { saham menggunakan Sharia Online Trading System (SOTS). SOTS } \\
\text { dikeluarkan oleh perusahaan anggota bursa sebagai bentuk } \\
\text { sistem yang merepresentasikan regulasi transaksi pasar modal } \\
\text { sebagai wujud upaya internalisasi prinsip halal di Pasar Modal. } \\
\text { SOTS hadir sebagai upaya aktualisasi penerapan nilai-nilai syariah } \\
\text { di pasar modal yang mudah dan sistematik. Manfaat penggunaan } \\
\text { SOTS antara lain; pertama, secara sistemik otomatis tidak bisa } \\
\text { membeli saham-saham yang tidak masuk kedalam kategori } \\
\text { syariah. Kedua, secara transaksi tidak bisa melakukan aktifitas } \\
\text { seperti short selling dan margin trading yang kedua konsep } \\
\text { tersebut tidak diperkenankan oleh DSN-MUI. }\end{array}$ \\
\hline
\end{tabular}

\section{Pendahuluan}

Perjalanan pasar modal syariah di Indonesia dimulai dengan diterbitkannya Reksa Dana Syariah pada pada tanggal 3 Juli 1997 oleh PT. Danareksa Investment Management. Yang kemudian dilanjutkan dengan gerakan oleh Bursa Efek Indonesia berkerjasama dengan PT. Danareksa Investment Management yang meluncurkan 
indeks saham bernama JII ( Jakarta Islamic Index) pada tanggal 3 Juli 2000 yang bertujuan sebagai acuan investor yang ingin menginvestasikan dananya secara syariah di instrumen saham. Dengan hadirnya indeks tersebut, maka para investor telah disediakan saham-saham yang dapat dijadikan sarana berinvestasi sesuai dengan prinsip syariah. ${ }^{1} \mathrm{JII}$ tersebut berisi 30 saham syariah pilihan yang liquid.

Pada dasarnya pasar modal sebagai instrument insvestasi memiliki return yang lebih menarik jika dibandingkan dengan obligasi mapun deposito. Namun terdapat kegalauan umat muslim di Indonesia karena terdapat beberapa argument yang menyatakan adanya adanya transaksi gharar, maysir, hingga bidang kerja perusahaannya apakah halal atau haram dan lain sebagainya. Hal-hal tersebut yang kemudian menjadi embrio lahirnya pasar modal syariah. Tidak sampai disitu, beberapa kegalauan lanjutan lain yang dirasakan para Investor yang ingin berinvestasi saham secara syariah, diantaranya adalah kesulitan memilih dan memilah saham mana saja yang sesuai syariah dan masuk dalam kategori DES (Daftar Efek Syariah) yang telah di filterisasi oleh OJK dan DSN-MUI.

Selain hal tersebut, yang menjadi penghambat perkembangan Pasar Modal adalah banyak penggunaan diksi ataupun bahasa yang "njlimet" hal tersebut yang membuat banyak masyarakat yang tidak mengerti dan tidak tertarik dengan investasi saham. ${ }^{2}$ Namun, seiring berlalunya waktu dan perkembangan teknologi sangat membantu dalam bertransaksi dan berinvestasi di instrumen saham, terlebih di era saat ini. Tidak hanya Perbankan, transaksi secara online juga merambah pasar modal Indonesia. fasilitas online trading telah disediakan oleh beberapa perusahaan sekuritas. Fasilitas perdagangan secara online tersebut dimaksudkan untuk memudahkan investor melakukan transaksi secara langsung di pasar modal. Sejalan dengan munculnya Fatwa No. 80 tahun 2011 tentang Penerapan Prinsip Syariah dalam Mekanisme Perdagangan Efek Bersifat Ekuitas di Pasar Reguler Bursa Efek, maka beberapa anggota bursa mulai menyediakan fasilitas Sistem Online Trading Syariah (SOTS).

Selain menjawab tentang berinvestasi saham, Sharia Online Trading System juga menjadi bukti kemajuan ekonomi syariah di industri pasar modal, juga sebagai upaya menjadikan Pasar Modal Indonesia yang lebih bersyariah. Disisi lain juga memudahkan setiap investor yang ingin berinvestasi saham karena dibarengi dengan teknologi yang memudahkan, bisa diakses melalui laptop/pc maupun smartphone.

Secara sederhana, sebenarnya SOTS merupakan sistem transaksi saham syariah secara online yang memenuhi prinsip-prinsip syariah yang dikembangkan oleh Anggota Bursa/Perusahaan Sekuritas yang dalam proses operasionalnya telah disertifikasi oleh DSN-MUI. Terakhir, perkembangan sharia online trading system per Juni 2020 sudah dimiliki oleh 18 perusahaan Anggota Bursa yang ada di Indonesia, ${ }^{3}$

\footnotetext{
${ }^{1}$ Otoritas Jasa Keuanga, https://www.ojk.go.id/id/kanal/pasar-modal/Pages/Syariah.aspx

2 Nicky Hogan, Simple Stories For A Simple Investor; Stop being "Njlimet",( Jakarta: PT Elex Media Komputindo, 2019, ) h. 168.

${ }^{3}$ Bursa Efek Indonesia, lihat, https://www.idx.co.id/idx-syariah/transaksi-sesuai-syariah/.
} 
dan uniknya lagi SOTS ini hanya ada di pasar modal Indonesia. ${ }^{4}$ dari hal tersebut membuat penulis ingin menyampaikan pesan penting SOTS melalui sebuah paper dengan judul "Penerapan Prinsip Syariah di Pasar Modal Melalui SOTS (Sharia Online Trading System).

\section{Kajian Teori}

\section{Pasar Modal dan Instrumennya}

Pasar modal merupakan tempat untuk memperdagangkan berbagai instrumen invetasi, baik dalam bentuk modal maupun hutang. Undang-Undang No 8 Tahun 1995 tentang Pasar Modal mendefinisikan pasar modal sebagai kegiatan yang berkaitan dengan penawaran umum dan perdagangan efek yang diterbitkannya, serta lembaga dan profesi yang berkaitan dengan efek. Perbedaan mendasar antara pasar modal dan pasar-pasar lainnya adalah terletak pada objek yang ditransaksikan. Dalam pasar modal, yang menjadi objek transaksi adalah saham, obligasi, dan berbagai instrumen derivatif lainnya seperti option, obligasi, dan berbagai instrumen derivatif lainnya. ${ }^{5}$

Pasar modal mampu menjembatani bagi pihak yang kelebihan dana dan membutuhkan modal. Pada sisi lain, pemodal juga dapat melakukan investasi di pasar modal dengan membeli efek-efek tersebut. Kegiatan di pasar modal dapat dikategorikan sebagai kegiatan ekonomi yang termasuk dalam kegiatan muamalah. ${ }^{6}$ Keunggulan lain dari investasi di pasar modal merupakan salah satu jenis investasi yang kini tengah booming alias digandrungi. Dikatakan digandrungi karena memberikan imbal hasil yang menarik jika dibandingkan dengan investasi lain seperti tabungan maupun deposito ${ }^{7}$

Pasar modal memilik peranan penting dalam aktivitas perekonomian suatu negara, diantaranya.

a. Sebagai fasilitas interaksi antara pembeli dan penjual untuk menentukan harga surat berharga yang diperjual belikan.

b. Alternatif penghimpunan dana masyarakat diluar lembaga perbankan

c. Memungkinkan para Investor untuk melakukan diversifikasi secara efektif sesuai dengan preferensi resikon

\footnotetext{
${ }^{4}$ Irwan Abdalloh, Pasar Modal Syariah, Jakarta: PT Elex Media Komputindo, h. 135

${ }^{5}$ Muhammad Firdaus NH, Sofiniyah Ghufron, Muhammad Aziz Hakim, Mukhtar Alshodiq, Briefcase Book Edukasi Profesional Syariah; Sistem Kerja Pasar Modal Syariah, (Jakarta; RENAISAN, 2005), h.16.

${ }^{6}$ Ahmad Faqih, Praktik Jual Beli Saham Syari'ah Perspektif Hukum Islam, Jurnal IQTISAD - Volume 5, Nomor 1, Juni 2018 ISSN: 2303-3223, h. 47.

${ }^{7}$ Irfan Noor Riza, Panen Dollar dari Bermain Saham; Ramuan Sukses Main Saham, Yogyakarta: CV Solusi Distribusi, 2014. H. 14.
} 
d. Memberikan kesempatan kepada para investor untuk memperoleh hasil (return) yang diharapkan

e. Memberikan kesempatan kepada para investor untuk menjual kembali surat berharga yang dimiliki

f. Menciptakan kesempatan kepada masyarakat untuk berpartisipasidalam perkembangan ekonomi

g. Memungkinkan alokasi dana dan sumberdaya secara efisien. ${ }^{8}$

Sama seperti pasar pada umumnya, namun yang membedakan Pasar Modal dengan pasar pada umumnya adalah objek yang diperjual belikan. Dalam pasar modal terdapat bebera instrumen yang diperdagangkan, diantaranya;

\section{a. Reksadana}

Reksadana dikenal dengan mutual fund. Dalam Undang-Undang Pasar Modal No 08 Tahun 1995 pasal 1 ayat 27 menyatakan bahwa reksa dana adalah wadah yang digunakan untuk mengimpun dana dari masyarakat pemodal untuk selanjutnya diinvestasikan dalam portofolio efek oleh manajer investasi. ${ }^{9}$ Yang dimaksud manajer investasi yaitu pihak yang kegiatan usahanya mengelola portofolio efek untuk para nasabah atau mengelola portofolio investasi kolektif untuk kelompok nasabah. ${ }^{10}$

Reksadana juga merupakan salah satu strategi diversifikasi dalam berinvestasi dan merupakan alternatif investasi bagi masyarakat pemodal, khususnya pemodal kecil dan pemodal yang tidak memiliki banyak waktu dan keahlian untuk menghitung return dan risiko atas investasi mereka. ${ }^{11}$

\section{b. Obligasi}

Obligasi merupakan salah satu instrument keuangan yang cukup menarik bagi kalangan investor, baik individu maupun institusi. Sebelum lebih jauh, sebaiknya dipahami dulu arti obligasi secara umum. Obligasi merupakan surat utang jagka panjag yang diterbitkan oleh suatu lembaga, dengan nilai nominal dan jatuh tempo tertentu. Penerbitan obligasi bisa perusahaan swasta, BUMN/BUMD atau pemerintah, baik pemerintah pusat maupun daerah. Salah satu jenis obligasi

\footnotetext{
8 Muhammad Nafik HR, Bursa Efek \& Investasi Syariah, Jakarta: PT. Serambi Ilmu Semesta, 2009, h. 148.

${ }^{9}$ Nurul Huda,Mustafa Edwin Nasution, Investasi pada Pasar Modal Syariah,( Jakarta; KENCANA, 2014), h. 109.

${ }^{10}$ Ahmad Ifham Sholihin, Pedoman Umum Lembaga Keuangan Syariah, Jakarta: PT Gramedia, 2010, h. 309.

${ }^{11}$ Winda Waridah, Elis Mediawati, Analisis Kinerja Reksadana Syariah, JURNAL RISET AKUNTANSI DAN KEUANGAN, 4 (2), 2016, h. 1077-1086.
} 
yang diperdagangkan di pasar modal kita saat ini adalah obligasi kupon (coupon bond) dengan tingkat bunga tetap selama masa berlaku obligasi. ${ }^{12}$

Teranyar, obligasi yang diterbitkan oleh pemerintah yaitu jenis SBR (saving bond ritel) pada bulan september 2019. Pemerintah kembali menawarkan instrumen Surat Utang Negara (SUN) ritel kepada investor individu secara online (eSBN)dengan tingkat kupon mengambang yaitu Savings Bond Ritel (SBR) seri SBR008. ${ }^{13}$

\section{c. Saham}

Intsrumen pasar modal yang sedang booming saat ini adalah saham. Saham merupakan surat berharga yang besifat kepemilikan. Artinya pemilik saham merupakan pemilik perusahaan. Semakin besar saham yang dimilikinya, semakin besar pula kekuasaannya di perusahaan tersebut. Keuntungan yang diperoleh dari saham dikenal dengan nama dividen. Pembagian dividen ditentukan dalam Rapat Umum Pemegang Saham. ${ }^{14}$

Terdapat dua sumber keuntungan dalam berinvestasi saham yaitu capital gain dan dividen. Capital gain merupakan keuntungan yang diperoleh pemegang saham apabila harga jual saham melebihi harga belinya. Selain capital gain, investasi saham memiliki potensi pendapatan dari dividen yang dibagikan oleh emiten. Dividen sendiri menurut Tjiptono Darmadji dan Hendy M. Fakhruddin dalam (Retno dan Putri, 2016) bahwa dividen merupakan pembagian sisa laba bersih perusahaan yang didistribusikan kepada pemegang saham. ${ }^{15}$

\section{Saham dalam Dimensi Konvensional dan Syariah}

Secara konsep saham merupakan surat berharga bukti penyertaan modal kepada perusahaan, dengan bukti penyertaan tersebut pemegang saham berhak untuk mendapatkan bagian hasil dari usaha perusahaan tersebut. Konsep pemerataan modal dengan hak bagian hasil usaha ini merupakan konsep yang tidak bertentangan dengan prinsip syariah. Prinsip syariah mengenal konsep ini sebagai kegiatan musyarakah atau syirkah. Berdasarkan analogi tersebut, maka secara konsep saham merupakan efek yang tidak bertentangan dengan prinsip syariah.

Pengertian saham syari'ah menurut OJK adalah surat berharga bukti penyertaan modal kepada perusahaan dan dengan bukti penyertaan tersebut pemegang saham berhak untuk mendapatkan bagian hasil dari usaha perusahaan tersebut. Konsep penyertaan modal dengan hak bagian hasil usaha ini

\footnotetext{
12 Najmuddin dan Faisal Amri, Komparasi Obligasi Dan Sukuk Sebuah Tinjauan Fenomenologis, TSARWAH (Jurnal Ekonomi dan Bisnis Islam), Volume 1 No. 1 (Januari-Juni) 2016, h. 2.

${ }^{13}$ Kementerian Keuangan Republik Indonesia, https://www.djppr.kemenkeu.go.id/page/load/2593.

${ }^{14}$ Yenni Samri Juliati Nasution, Peranan Pasar Modal Dalam Perekonomian Negara, HUMAN FALAH: Volume 2. No. 1 Januari - Juni 2015.

${ }^{15}$ Retno M.E.L dan Putri Permatasari, Studi Terhadap Pembagian Dividen Dan Dampaknya Terhadap Harga Saham Perusahaan-Perusahaan Yang Terdaftar Di Bursa Efek Indonesia Periode 2011-2014, JIAFE (Jurnal Ilmiah Akuntansi Fakultas Ekonomi) Volume 2 No. 1 Tahun 2016 Edisi 2, Hal. 69-85.
} 
merupakan konsep yang tidak bertentangan dengan prinsip syariah. Prinsip syariah mengenal konsep ini sebagai kegiatan musyarakah atau syirkah. ${ }^{16}$

Secara konsep, saham merupakan surat berharga bukti penyertaan modal kepada perusahaan dan dengan bukti penyertaan tersebut, kemudian pemegang saham berhak untuk mendapatkan bagian hasil dari usaha perusahaan tersebut. Konsep penyertaan modal dengan hak bagian hasil usaha ini merupakan konsep yang tidak bertentangan dengan prinsip syariah. Prinsip syariah mengenal konsep ini sebagai kegiatan musyarakah atau syirkah. Berdasarkan analogi tersebut, maka secara konsep saham merupakan efek yang tidak bertentangan dengan prinsip syariah. Namun demikian, tidak semua saham yang diterbitkan oleh Emiten dan Perusahaan Publik dapat disebut sebagai saham syariah.

Terdapat beberapa pelanggaran Syariah terhadap saham yang sudah semestinya untuk dicermati dan dibenahi untuk menjadikan pasar modal Indonesia yang lebih bersyariah. Saat ini masih banyak aktivitas pasar modal Indonesia yang bertentangan atau melanggar prinsip syariah, diantaranya Muhammad Nafik dijelaskan:

a. Sekuritas yang diperdagangkan merupakan emiten yang memproduksi barang dan jasa yang haram serta melanggar syariah.

b. Menjual sekuritas yang belum dimiliki

c. Transaksi yang mengandung ketidakjelasan sekuritas yang diperdagangkan

d. Transaksi mengandung unsur riba

e. Rekayasa permintaan dan penawaran untuk mempermainkan harga, dan lainlain. ${ }^{17}$

\section{Regulasi Saham Syariah Berdasarkan Emiten}

Pihak Otoritas Jasa Keuangan telah mengatur tentang regululasi kriteria terkait saham syariah yang tertuang dalam peratutan No IX.A.13 tentang Pasar Modal Syariah, beberapa poin didalamnya yaitu tidak melakukan kegiatan usaha: perjudian dan permainan yang tergolong judi; perdagangan yang tidak disertai dengan penyerahan barang/jasa; perdagangan dengan penawaran/permintaan palsu; bank berbasis bunga; perusahaan pembiayaan berbasis bunga;jual beli risiko yang mengandung unsur ketidakpastian (gharar) dan/atau judi (maisir), antara lain asuransi konvensional; memproduksi, mendistribusikan, memperdagangkan dan/atau menyediakan barang atau jasa haram zatnya, barang atau jasa haram bukan karena zatnya yang ditetapkan oleh DSN-MUI; dan/atau, barang atau jasa yang merusak moral dan bersifat mudarat; melakukan transaksi yang mengandung unsur suap (risywah).

\footnotetext{
${ }^{16}$ Choirunnisak, Saham Syariah ; Teori Dan Implementasi, Jurnal SLAMIC BANKING: Jurnal Pemikiran dan Perkembangan Perbankan Syariah, Volume 4 Nomor 2Februari 2019, h. 68.

${ }^{17}$ Muhammad Nafik HR, Bursa Efek dan Investasi Syariah, Jakarta: PT Serambi Ilmu Semesta, 2009, h. 201.
} 
Secara gampang, Irwan Abdalloh (Kepala Divisi Pasar Modal Syariah Bursa Efek Indonesia) mengatakan bahwa emiten atau perusahaan publik yang sahamnya masuk seleksi saham syariah adalah emiten yang dalam anggaran dasarnya tidak menyatakan sebagai perusahaan yang memenuhi prinsip syariah. ${ }^{18}$ Seleksi tersebut dilakukan oleh Otoritas Jasa Keuangan setiap enam bulan sekali, yang ditinjau oleh tim khusus terdiri dari perwakilan OJK, DSN-MUI dan Bursa Efek Indonesia sebelum daftar saham syariah tersebut terbit ke publik.

Ketentuan lain didalamnya termasuk dalam rasio keuangan, OJK dan DSN-MUI telah mengatur, beberapa batas toleransi seperti rasio total hutang berbasis bunga terhadap total aset tidak lebih dari 45\%, yang dimaksud utang ini adalah utang yang berasal dari perbankan konvensional, penerbitan obligasi atau utang sejenis yang menggunakan perhitungan bunga. ${ }^{19}$ Selain hal tersebut rasio total pendapatan bunga dan total pendapatan tidak halal lainnya dibandingkan total pendapatan usaha dan total pendapatan lainnya tidak lebih dari $10 \%{ }^{20}$

\section{Regulasi Saham Syariah Berdasarkan Transaksi}

Fatwa DSN-MUI No 80/DSN-MUI/III/2011 Tentang Penerapan Prinsip Syariah Dalam Mekanisme perdagangan Efek Bersifat Ekuitas Di Pasar Reguler Bursa Efek terdapat penolakan terhadap beberapa transaksi yang biasa terjadi di pasar modal, diantaranya melarang;

\section{a. Short selling}

Short selling merupakan sebuah aktivitas yang memungkinkan anda untuk menjual sebuah saham perusahaan tanpa harus memilikinya terlebih dahulu. Broker/sekuritas akan menggunakan saham milik mereka, atau mereka akan meminjam saham dari investor lain agar anda dapat menjual saham tersebut terlebih dahulu. Aksi short selling saham termasuk dalam transaksi saham margin, yang berarti anda harus memiliki akun margin terlebih dahulu untuk melakukannya.

Short selling dalam Fatwa DSN-MUI dijelaskan sebagai Bai' al-Maksyuf, yaitu bentuk jual beli yang mengandung gharar;yaitu jual beli secara tunai atas barang (efek) yang bukan milikpenjual dan penjual tidak diberi izin oleh pemilik untuk menjualkan, atau jual beli secara tunai atas barang (efek) padahal penjual tidak memiliki barang (efek) yang dijualnya. ${ }^{21}$

\section{b. Margin trading}

Tindakan ini tidak diperbolehkan karena yang termasuk dalam kategori riba, karena margin trading (transaksi dengan pembiayaan), atau melakukan

\footnotetext{
${ }^{18}$ Irwan Abdalloh, Pasar Modal Syariah, Jakarta: PT Elex Media Komputindo, 2018, h. 87

${ }^{19}$ Ibid., h. 90.

${ }^{20}$ Lihat, https://www.ojk.go.id/id/kanal/pasar-modal/Pages/Syariah.aspx.

${ }^{21}$ Fatwa DSN-MUI NO 80 Tahun 2011 Tentang Mekanisme Transaskie perdagangan Efek Bersifat Ekuitas Di Pasar Reguler Bursa Efek. (https://dsnmui.or.id/kategori/fatwa/page/5/)
} 
transaksi efek dengan fasilitas pinjaman berbasis bunga (riba) kewajiban penyelesaian terhadap pembelian Efek; ${ }^{22}$ fasilitas ini diberikan oleh perusahaan sekuritas kepada investor yang menginginkannya

\section{SOTS (Sharia Online Trading System)}

Shariah Online Trading System (SOTS) merupakan salah satu layanan online trading sistem yang di desain berdasarkan prinsip-prinsip syariah yang diturunkan dari fatwa DSN-MUI No. 80. Fitur-fitur standart dalam shariah online trading system secara umum adalah fitur jual-beli saham, update perkembangan harga saham setiap waktu, indikator untuk menganalisa pergerakan harga saham, berita-berita yang berkaitan dengan perusahaan dan fitur keuangan pelaku pasar. ${ }^{23}$

Beberapa fitur utama SOTS diantaranya hanya saham syariah yang dapat ditransaksikan. Transaksi beli saham syariah hanya dapat dilakukan secara tunai (cash-basis transaction) sehingga tidak boleh ada transaksi margin (margin trading). Tidak dapat melakukan transaksi jual saham syariah yang belum dimiliki (short selling). Laporan kepemilikan saham syariah dipisah dengan kepemilikan uang sehingga saham syariah yang dimiliki tidak dihitung sebagai modal (uang). Memang belum semuaHingga saat ini Saat ini terdapat 18 Anggota Bursa yang sudah memiliki SOTS.

Tabel. 1 Daftar SOTS di Indonesia

\begin{tabular}{llll}
\hline NO & \multicolumn{1}{c}{ ANGGOTA BURSA } & \multicolumn{1}{c}{ NAMA SOTS } & AKSES LINK \\
\hline 1 & PT Indo Premier Sekuritas & IPOT Syariah & www.indopremier.com \\
\hline 2 & PT Mirae Asset Sekuritas & HOTS Syariah & www.miraeasset.co.id \\
\hline 3 & PT BNI Sekuritas & e-Smart Syariah & www.bnisekuritas.co.id \\
\hline 4 & PT Trimegah Sekuritas Tbk. & iTrimegah Syariah & www.trimegah.com \\
\hline 5 & PT Mandiri Sekuritas & MOST Syariah & www.most.co.id \\
\hline 6 & PT Panin Sekuritas Tbk. & POST Syariah & www.pans.co.id \\
\hline 7 & PT Phintraco Sekuritas & PROFITS Syariah & www.profits.co.id \\
\hline 8 & PT Sucor Sekuritas & SPOT Syariah & $\begin{array}{l}\text { https://sucorsekuritas.c } \\
\text { om/ }\end{array}$ \\
\hline 9 & PT FAC Sekuritas & FAST Syariah & www.facsekuritas.co.id
\end{tabular}

\footnotetext{
22 Adri Soemitro, Hukum Ekonomi Syariah dan Fiqh Muamalah; di Lembaga Keuaga dan Bisnis Kontemporer, (Jakarta Timur: Prenadamedia Group, 2019), h. 239.

${ }^{23}$ Yusi Septa Prasetia, "Implementasi Regulasi Pasar Modal Syariah Pada Sharia Online Trading System (SOTS)", Jurnal IAIN Ponorogo, NIZHAM, Vol. 05, No. 02, Juli-Desember, 2017, h. 29
} 


\begin{tabular}{llll}
\hline 10 & PT MNC Sekuritas & MNC Trade Syariah & www.mncsekuritas.id \\
\hline 11 & PT Henan Putihrai Sekuritas & HPX Syariah & $\begin{array}{l}\text { www.hpfinancials.co.id } \\
\text { /hps }\end{array}$ \\
\hline 12 & $\begin{array}{l}\text { PT Philip Sekuritas } \\
\text { Indonesia }\end{array}$ & POEM Syariah & www.poems.co.id \\
\hline 13 & PT RHB Sekuritas & $\begin{array}{l}\text { RHB Trade Smart } \\
\text { Syariah }\end{array}$ & $\begin{array}{l}\text { https://rhbtradesmart. } \\
\text { co.id/ }\end{array}$ \\
\hline 14 & PT Samuel Sekuritas & STAR Syariah & https://samuel.co.id/ \\
\hline 15 & $\begin{array}{l}\text { PT Maybank Kim Eng } \\
\text { Sekuritas }\end{array}$ & KE Trade Syariah & $\begin{array}{l}\text { https://www.maybank- } \\
\text { ke.co.id/ }\end{array}$ \\
\hline 16 & PT OSO Sekuritas Indonesia & OSO Trader Syariah & $\begin{array}{l}\text { http://www.oso- } \\
\text { securities.com }\end{array}$ \\
\hline 17 & PT Kresna Sekuritas & $\begin{array}{l}\text { Kresna Trader } \\
\text { Syariah }\end{array}$ & $\begin{array}{l}\text { http://www.kresnasecu } \\
\text { rities.com }\end{array}$ \\
\hline 18 & PT Danareksa Sekuritas & $\begin{array}{l}\text { Danareksa Online } \\
\text { Trading Syariah }\end{array}$ & $\begin{array}{l}\text { http://danareksasekurit } \\
\text { as.co.id/ }\end{array}$ \\
\hline
\end{tabular}

Sumber: Bursa Efek Indonesia, 2020

Irwan Abdalloh dalam bukunya Pasar Modal Syariah mengatakan bahwa SOTS diciptakan untuk memudahkan investor syariah dalam melakukan transaksi saham syariah. Proses operasional dan mekanisme SOTS mengacu kepada Fatwa DSN-MUI No 80. Prakti yang terjadi dalam aplikasi tersebut adalah jabaran dari transaksi yang tidak diperkenankan dalam Fatwa tersebut. Dan SOTS hanya ada di Indonesia. ${ }^{24}$ Dengan bahasa sederhana karena merupakan penjabaran dari fatwa DSN-MUI No. 80 tahun 2011 tentang Penerapan Prinsip Syariah Dalam Mekanisme Perdagangan Efek Bersifat Ekuitas Di Pasar Reguler Bursa Efek. Fitur utama SOTS adalah sebagai berikut:

a. Hanya saham syariah yang dapat ditransaksikan.

b. Transaksi beli saham syariah hanya dapat dilakukan secara tunai (cash-basis transaction) sehingga tidak boleh ada transaksi margin (margin trading).

c. Tidak dapat melakukan transaksi jual saham syariah yang belum dimiliki (short selling).

d. Laporan kepemilikan saham syariah dipisah dengan kepemilikan uang sehingga saham syariah yang dimiliki tidak dihitung sebagai modal (uang). ${ }^{25}$

\footnotetext{
${ }^{24}$ Irwan Abdalloh, Pasar Modal Syariah,...., h. 135

25 Dini Selasi, Implementasi Ekonomi Syariah Pada Perkembangan Investasi Saham Syariah Di Era Distrupsi, JURNAL INKLUSIF : Jurnal Pengkajian Penelitian Ekonomi dan Hukum Islam Vol:4 No:1 Juni
} 


\section{Metode}

Tulisan ini termasuk kedalam studi pustaka, metode yang digunakan adalah kualitatif dengan pengambilan data melalui informasi yang relevan dengan topik atau masalah yang akan atau sedang diteliti. Informasi tersebut diperoleh dari buku-buku ilmiah, laporan penelitian, karangan-karangan ilmiah, ketetapan-ketetapan, ensiklopedia, dan sumber-sumber tertulis baik tercetak maupun elektronik. Pendekatan yang dilakukan adalah deskriptif, pendekatan ini digunakan agar memperoleh gambaran jawaban terkait Sharia Online Trading System (SOTS) dan penerapan prinsip yariah didalamnya.

\section{Hasil dan Pembahasan}

\section{Efesiensi dan Kemudahan Transaki Sharia Online Trading System}

Sejarah modernisasi industri pasar modal terjadi pada tahun 1995, dengan mulai diberlakukannya JATS (Jakarta Auoto Trading Sysyem). Gerakan tersebut merupakan sebuah perdagangan dilantai bursa yang secara otomatis dalam transaksi jual dan beli saham. Sebelum kehadiran JATS transaksi di Bursa Efek Indonesia, awalnya transaksi masih dengan cara klasik dan manual. Semisal dengan papan tulis, dan sebagai bukti kepemilikan atas saham tertentu dengan diberikan lembaran warkat tiap per lembar saham. Cara klasik tersebut sangat tidak efisien karena membuat penyelesaian transaksi begitu lama dan diberikannya warkat sebagai bukti kepemilikan saham mempunyai resiko rusaknya warkat maupun hilang.

Lambat laun, perdagangan saham menggunakan Sistem online Trading yang membuat transaksi lebih mudan dan cepat. Bisa diakses melalui smartphone maupun pc selagi ada akses internet. Disisi lain itu tidak ada lagi penggunaan warkat sebagai bukti kepemilikan saham, namun menggunakan bukti pembelian (trade confirmation) yang dikirimkan ke email investor setiap transaksi jual ataupun beli. Hal tersebut lebih praktis dan aman jika dibandingan dengan warkat.

Tonggak kebangkitan pasar modal syariah Indonesia diawali dengan diluncurkannya Indeks Saham Syariah Indonesia (ISSI) sebagai indeks komposit saham syariah, yang terdiri dari seluruh saham syariah yang tercatat di Bursa Efek Indonesia (BEI), pada tahun 2011. Kemudian diikuti dengan diluncurkannya Syariah Online Trading System(SOTS) oleh perusahaan efek pada tahun yang sama. SOTS adalah sistem pertama di dunia yang dikembangkan untuk memudahkan investor syariah dalam melakukan transaksi saham sesuai prinsip islam. Pada tahun 2013, Bank Syariah Mandiri menjadi Bank RDN Syariah pertama. ${ }^{26}$

2019 Published by Pascasarjana IAIN Syekh Nurjati Cirebon, Indonesia. p-ISSN: 2303-2669, e-ISSN: 25489631

${ }^{26}$ Daftar AB-SOTS, Bursa Efek Indonesia https://ww w.idx.co.id/idx-syariah/. 
Kehadiran Sistem Online Trading Syariah membuat proses transaksi di pasar saham lebih mudah dan efisien. Mudah dalam artian setiap elemen masyarakat bisa mengangkses asal ada internet melalui media smartphone maupun laptop karena dibarengi dengan tekhnologi yang memudahkan untuk bertransasksi.

SOTS hadir dituntut untuk dapat diaplikasikan pada perangkat bergerak (mobile) seperti HP, PDA, smartphone. Hal ini tidak terlepas dari trend dan gaya hidup sekarang dimana masyarakat luas sudah mulai mengenal internet dan koneksi online. Ketergantungan terhadap perangkat mobile pun tinggi. Melihat kondisi tersebut maka aplikasi teknologi informasi yang diusulkan adalah menggunakan aplikasi yang berbasis teknologi mobile dan menggunakan perangkat mobile seperti, smartphone dan tablet. ${ }^{27}$

Akibat dari kemudahan-kemudahan tersebut juga usaha gencar dari Bursa Efek Indonesia dan pihak terkait lainnya dalam menyebarkan luas literasi pasar modal, wajar jikalau pertumbuhan Investor Saham Syariah Indonesia mengalami peningkatan dalam beberapa tahun terakhir. Bursa Efek Indonesia mencatat yang tertuang dalam tabel dibawah ini:

Tabel 2. Jumlah Ivestor Saham Syariah

\begin{tabular}{cc}
\hline Tahun & Jumlah \\
\hline 2016 & 17.000 \\
\hline 2017 & 23.000 \\
\hline 2018 & 45.000 \\
\hline \multicolumn{2}{l}{ Sumber: Laporan Tahunan BEI 2019}
\end{tabular}

\section{Penerapan Prinsip Syariah di Pasar Modal Melalui Sharia Online Trading System}

Menjadi investor saham syariah harus lebih hati-hati dibanding dengan investor non-syariah. Ada beberapa hal yang harus dihindarkan oleh seorang investor saham syariah pada saat melakukan transaksi saham syariah agar tidak menjadi transaksi sesuai dengan prinsip Islam.

Salah satu karakteristik utama saham syariah yang telah disampaikan diatas adalah bisninya harus halal. Yakni secara umum tidak terlibat terhadap aktivitas-aktivitas yang dilarang, seperti perjudian, penjualan minuman keras atau bisnis yang melibatkan riba dan gharar. Namun, yang sering menjadi diskusi adalah jika sektor usaha bisnisnya halal namun dalam beberapa bagian semisal modal ada bercampur dengan dan melibatkan aktifitas berbasis bunga, semisal pinjaman yang diambil

\footnotetext{
${ }^{27}$ Herlina Yustati, Efektivitas Pemanfaatan Sistem Online Trading Syariah Dalam Meningkatkan Investor Saham Di Pasar Modal Syariah, SYI'AR IQTISHADI Journal of Islamic Economics, Finance and Banking Vol.1 No.2, November 2017, h. 116.
} 
dari perbankan kovensional. Sebagian berpendapat bahwa jual beli semacam ini tidak diperbolehkan karena telah menabrak praktik yang menentang syariah. ${ }^{28}$

Pada faktanya sangat jarang ditemukan perusahaan yang $100 \%$ bersyariah, dalam artian setiap aspek bisnis mereka sepenuhnya sesuai dengan syariah. Definisi operasional yang ketat, mengenai apa artinya bisnis yang halal akan membuat kecilnya saham syariah yang ingin diinvestasikan oleh investor. Dalam buku Sistem Keuangan Islam (Prinsip dan Operasi) yang disusun oleh ISRA (International Sharia Research Academy For Islamic Finance) menyatakan bahwa banyak ulama yang berpendapat bahwa apabila sebagian bisnis terlibat dalam aktifitas yang tidak diperbolehkan, maka tidak sertamerta menjadikan keseluruhan bisnisnya tidak halal. Jadi, keputusan-keputusan syariah tentang saham memang mempertimbangkan realitas saat ini di dalam masyarakat dan kemaslahatan. ${ }^{29}$

Pertimbangan-pertimbangan tersebut yang selanjutnya mengahadirkan berapa presentase aktifitas tidak halal yang diperbolehkan. Seperti yang telah tertulis sebelumnya bahwa regulasi nya adalah seperti rasio total hutang berbasis bunga dibandingkan total ekuitas tidak lebih dari $82 \%$. Aturan tersebut yang nantinya membuat klasifikasi saham yang masuk dalam DES ( Daftar Efek Syariah).

Beberapa upaya lain dalam penerapan prinsip halal melalui SOTS, pertama yakni hanya saham syariah yang bisa ditransaksikan. SOTS mampu men-fiter saham yang tidak termasuk dalam ISSI. Ketika saham tersebut bukan kategori saham syariah maka dengan otomatis akan tertolak secara sistem sewaktu investor akan membelinya. Disisi lain hal tersebut membuat transaksi dan penerapan prinsip halal di pasar modal menjadi mudah. Karena investor tidak perlu repot-repot melihat indeks ISSI (Indeks Saham Syariah Indonesia) yang jumlahnya ratusan untuk memastikan saham yang ingin dibeli masuk kategori tersebut atau tidak.

Kedua, tidak diperbolehkannya ada transaksi short selling dan margin trading. Kedua transaksi tersebut merupakan skema jual beli saham yang menarbrak prinsip syariah. Secara umum, praktek short selling adalah transaksi penjualan suatu sekuritas yang pada saat transaksi tidak dimiliki oleh investor penjual. Konsep dari short selling ini melibatkan peminjaman saham yang investor penjual tidak miliki, menjual saham yang telah dipinjam tersebut, dan kemudian membeli dan mengembalikan saham ketika harganya turun. Pada prakteknya di pasar saham, investor dapat meminta perusahaan broker untuk meminjam saham yang tidak dimiliki perusahaan tersebut dari orang lain, dan kemudian saham yang dipinjam tersebut ditawarkan di pasar untuk dijual. Investor harus membeli kembali saham tersebut dan mengembalikannya kepada pihak yang meminjamkan saham.

Short selling tidak sesuai dengan prinsip syariah karena menjual barang yang belum dimiliki. Hal tersebut sesuai dengan Hadits Rasulullah. Dari Hakim bin Hizam,

\footnotetext{
28 International Shari'ah Research Academy for Islamic Finance (ISRA), SISTEM KEUANGAN ISLAM: Prinsip dan Operasi, (Depok: RAJAGRAFINDO PERSADA, 2015), h. 543.

${ }^{29}$ Ibid., 543.
} 
"Beliau berkata kepada Rasulullah, 'Wahai Rasulullah, ada orang yang mendatangiku. Orang ters ebut ingin mengadakan transaksi jual beli, denganku, barang yang belum aku miliki. Bolehkah aku membelikan barang tertentu yang dia inginkan di pasar setelah bertransaksi dengan orang tersebut?' Kemudian, Nabi bersabda, 'Janganlah kau menjual barang yang belum kau miliki."' (HR. Abu Daud, no. 3505; dinilai sahih oleh Al-Albani)

Selain short selling, transaksi yang tidak bisa dilakukan dengan SOTS adalah margin trading. Karena margin trading merupakan praktek jual beli saham yang memperbolehkan investor untuk meminjam dana dari perusahaan sekuritas dengan tujuan membeli saham suatu perusahaan. Di pasar yang efisien, tanpa penggelembungan saham, praktek margin trading dapat membuat investor tergiur untuk membeli saham yang memiliki tingkat volatilitas tinggi sebagai portofolio investasinya dengan Margin trading biasanya dijadikan sebagai salah satu daya tarik oleh perusahaan sekuritas (broker) guna meningkatkan jumlah investor yang membeli saham melalui jasa yang mereka berikan. Dengan fasilitas margin trading, seorang investor dapat membeli saham melebihi modal yang ia miliki karena ia meminjam modal dari perusahaan sekuritas dengan ketika pengmbalian terdapat bunga setelahnya.

Konsep margin trading dikatan menabrak prinsip syariah karena terdapat aktivitas yang melibatkan unsur riba didalamnya, yaitu bunga pinjaman yang harus dibayarkan oleh investor karena telah meminjam sejumlah dana dengan nilai tertentu kepada perusahaan sekuritas. ${ }^{30}$ Hadirnya SOTS dengan tidak menngunakan konsep margin trading dalam proses transaksi jual-beli saham di pasar modal dapat kita pahami bersama sebagai upaya penerapan prinsip halal dalam pasar modal syariah. Selain hal tersebut, sisi lain dari margin trading adalah penuh dengan resiko cukup besar, Karena membeli saham tidak selalu mendapatkan keuntungan. Sedangkan membayar bunga hutang dari fasilitas margin trading adalah kepastian yang mengikat investor. Apabila gagal bayar maka perusahaan sekuritas akan menjual paksa saham-saham yang dimiliki investor tersebut.

SOTS juga mempunyai prinsip Cash Basis Transaction \& Pemisahan Portofolio, salah satu fitur penting dalam SOTS, karena investor tidak dapat bertransaksi melebihi jumlah uang yang dimiliki karena tidak ada fasilitas marjin. Jika jumlah pembelian melebihi nilai uang yang dimiliki, maka secara otomatis sistem akan menolak transaksi tersebut. Hal ini akan tetap berlaku walaupun investor memiliki jumlah saham yang sangat besar sekalipun karena memang ada pemisahan portofolio dimana saham tidak dapat dinilai sebagai uang. Hanya ada dua cara jika pembelian

\footnotetext{
${ }^{30}$ Muhammad Muhajir Aminy, Praktik Short Selling, Margin Trading, Dan Insider Trading Di Pasar Saham Dalam Perspektif Islam, Iqtishadun - Jurnal Ekonomi Dan Keuangan Islam, Volume IX, Nomor 1, Juni 2018.
} 
saham investor melebihi dana yang dimiliki, satu melakukan top up atas cash atau menjual saham yang dimiliki. ${ }^{31}$

\section{KESIMPULAN}

Terdapat beberapa hal yang tidak sesuai dengan prinsip syariah di Industri Pasar Modal. Mulai dari saham yang tidak sesuai dengan syariah hingga beberapa proses transaksinya. Dalam upaya lebih internalisasi prinsip halal di pasar modal yang lebih mudah dan berbasis tekhnologi hadirlah sharia online trading system (SOTS). Perkembangan tekhnologi sangat membantu dalam melakakukan transaksi secara online di dunia keuangan. Tidak hanya Perbankan, transaksi secara online juga merambah di Pasar Modal Indonesia. fasilitas online trading telah disediakan oleh beberapa perusahaan sekuritas. Fasilitas perdagangan secara online dimaksudkan untuk memudahkan investor melakukan transaksi. Dalam konsepnya, SOTS sebagai online trading terdapat beberapa nilai syariah yang diterapkan diantaranya; hanya saham-saham syariah yang dapat ditransasksikan secara sistemsik. Kedua, secara transaksi tidak bisa dilakukan aktifitas short selling dan margin trading yang kedua konsep tersebut tidak dibenarkan oleh DSN-MUI.

\section{DAFTAR PUSTAKA}

Abdalloh, Irwan, (2018) Pasar Modal Syariah, Jakarta: PT Elex Media Komputindo.

Aminy, Muhammad Muhajir, (2018), Praktek Short Selling, Margin Trading, Dan Insider Trading Di Pasar Saham Dalam Perspektif Islam, Iqtishadun - Jurnal Ekonomi Dan Keuangan Islam, Volume IX, Nomor 1, Juni.)

Amri, Faisal \& Najmuddin, (2016), Komparasi Obligasi Dan Sukuk Sebuah Tinjauan Fenomenologis, TSARWAH (Jurnal Ekonomi dan Bisnis Islam), Volume 1 No. 1 (Januari-Juni).

Choirunnisak, (2019) Saham Syariah ; Teori Dan Implementasi, Jurnal ISLAMIC BANKING: Jurnal Pemikiran dan Perkembangan Perbankan Syariah, Volume 4 Nomor 2 Februari 2019, h. 68.

Fajar, Muhammad Andryzal (2019), Perkembangan, Tantangan dan Peran Shariah Online Trading System (SOTS) di Pasar Modal Syariah Dalam Menghadapi Revolusi Industri 4.0, Prosiding STIE BPD Accounting Forum (SAF) Edisi 1 Desember 2019, ISBN 9786027436725.

Faqih, Ahmad (2018) Praktik Jual Beli Saham Syari'ah Perspektif Hukum Islam, Jurnal IQTISAD - Volume 5, Nomor 1, Juni 2018 ISSN: 2303-3223.

\footnotetext{
${ }^{31}$ Muhammad Andryzal Fajar, Perkembangan, Tantangan dan Peran Shariah Online Trading System (SOTS) di Pasar Modal Syariah Dalam Menghadapi Revolusi Industri 4.0, Prosiding STIE BPD Accounting Forum (SAF) Edisi 1 Desember 2019, ISBN 9786027436725, h. 394.
} 
Fatwa Dewan Syariah Nasional No. 80/DSN-MUI/III/2011 Tentang Penerapan Prinsip Syariah dalam Perdagangan Efek Bersifat Ekuitas di Pasar Reguler Bursa Efek.

Hogan, Nicky, (2019) Simple Stories For A Simple Investor; Stop being "Njlimet", Jakarta: PT Elex Media Komputindo.

Huda, Nurul, (2014) Investasi Pada pasar Modal Syariah, Jakarta: KENCANA.

Indonesia, Kementerian Keuangan Republik, https://www.djppr.kemenkeu.go.id/page/load/2593.

International Shari'ah Research Academy for Islamic Finance (ISRA), (2015)SISTEM KEUANGAN ISLAM: Prinsip dan Operasi, Depok: RAJAGRAFINDO PERSADA.

Laporan Tahunan Bursa Efek Indonesia Tahun 2019 (www.idx.co.id)

Mediawati, Elis \&Winda Waridah, Analisis Kinerja Reksadana Syariah, JURNAL RISET AKUNTANSI DAN KEUANGAN, 4 (2), 2016, h. 1077-1086.

Muhammad Firdaus NH, Sofiniyah Ghufron, Muhammad Aziz Hakim, Mukhtar Alshodiq, (2005), Briefcase Book Edukasi Profesional Syariah; Sistem Kerja Pasar Modal Syariah, Jakarta; RENAISAN.

Nafik HR, Muhammad, (2009) Bursa Efek \& Investasi Syariah, Jakarta: PT. Serambi Ilmu Semesta.

Nasution, Yenni Samri Juliati, (2015) Peranan Pasar Modal Dalam Perekonomian Negara, HUMAN FALAH: Volume 2. No. 1 Januari - Juni.

Otoritas Jasa Keuangan, https://www.ojk.go.id/id/kanal/pasarmodal/Pages/Syariah.aspx.

Permatasari, Putri \& Retno M.E.L, (2016), Studi Terhadap Pembagian Dividen Dan Dampaknya Terhadap Harga Saham Perusahaan-Perusahaan Yang Terdaftar Di Bursa Efek Indonesia Periode 2011-2014, JIAFE (Jurnal Ilmiah Akuntansi Fakultas Ekonomi) Volume 2 No. 1 Tahun 2016 Edisi 2, Hal. 69-85

Riza, Irfan Noor, (2014) Panen Dollar dari Bermain Saham; Ramuan Sukses Main Saham, Yogyakarta: CV Solusi Distribusi.

Sholihin, Ahmad Ifham, (2010) Pedoman Umum Lembaga Keuangan Syariah, Jakarta: PT Gramedia.

Soemitro, Adri, (2019), Hukum Ekonomi Syariah dan Fiqh Muamalah; di Lembaga Keuaga dan Bisnis Kontemporer, Jakarta Timur: Prenadamedia Group.

Yusi, Septa Prasetia, (2017) "Implementasi Regulasi Pasar Modal Syariah Pada Sharia online trading system (SOTS)", Jurnal IAIN Ponorogo, NIZHAM, Vol. 05, No. 02, Juli-Desember. 